\title{
Financial Management Practices And Profitability of Small Scale Enterprises Uganda, A Case of Kabale Municipality
}

\section{Marus Eton ( $\nabla$ emarus@kab.ac.ug )}

Kabale University Faculty of Economics and Management Sciences https://orcid.org/0000-0002-90578484

\section{Fabian Mwosi}

Uganda Christian University Bishop Barham University College

Eliab Byamukama Mpora

Kabarak University

\section{Bernard Patrick Ogwel}

Kampala International University

\section{Research}

Keywords: Financial Management Practices, Working Capital Management, Cash Management, Profitability, Small Scale Enterprises

Posted Date: August 24th, 2021

DOl: https://doi.org/10.21203/rs.3.rs-744961/v1

License: (c) (1) This work is licensed under a Creative Commons Attribution 4.0 International License. Read Full License 


\section{Abstract}

The purpose of the study was to examine how financial Management Practices affect profitability amongst small scale enterprises. The study adopted descriptive and correlational research designs. The study used a multi regression analysis that determined the linear effect of financial management practices on profitability. A multi regression model also provided a basis for hypothesis testing. The findings established a significant influence of financial management practices on profitability. Evidence showed that working capital and cash management practices had strong associations with profitability. This study also established a triad-factor that limits profitability, characterizing operational costs, microeconomic, and personal characteristics. This study provided empirical evidence on the contribution of the innovation theory and managerial efficiency theory of profits to management of operational and production costs in business. The study recommends that Small business firms should ensure sound financial management practices in order to experience positive changes in their profitability levels. Small scale enterprise owners must pay a lot of attention to their working capital dynamics, cash management which highly affect their profitability levels. Small scale entrepreneurs should hire professionals and experts in financial management.

\section{Introduction}

The business environment continues to experience constant evolution, which needs better business strategies to transform the business enterprises into those that can survive today's competitive market environments. This therefore, warrants reviving the financial management practices to meet the pressure that businesses are faced with. However, many businesses struggle to secure adequate cash flows, and working capital that are profitable (Siaw, 2014).Small scale enterprises are seen as the driving force behind the growth of most economies world over (Derbie and Kassahun, 2013).Financial Management Practices (FMP) such as Budget control, Working capital management, cash management, financial forecasting and analysis and financial decisions greatly affect the financial performances of small scale enterprises (Mbawuni, et al..., 2014).With that said, ineffective financial management practices has been the major cause of business failures, resulting in to shortage of funds due to mismanagement, inadequate budget allocation and high operational cost. The primary objective of setting up any business is to maximize profit. In order to attract others in your business enterprise or as a precondition for long term survival, business profitability is a major determinant (Prijadi and Desiana, 2017). Business enterprises should be in a position to know or project the profitability level of the firm in a specific period. Profitability would always remain as a measure of success in any business and without profit making no business can continue existing (Popa and Ciobanu, 2014). The global market trends have seen changes in the way businesses operate and these has made firms to adopt efficient FMP in order to remain competitive in the global market in abide to increase its productivity and remain profitable (Yunis et al..., 2018). Regardless of the firm's size, a good and effective financial management practice would spur the enterprise growth. Financial management practice is significant in helping the diversification of services and product lines, market penetration and planning on growth. 
Small scale enterprises play an important role in the growth and progress of an economy as they aggressively keep on seeking technological changes that are major in the transformation on an economy (OECD, 2017). However, Small scale enterprises are faced with difficulties in raising finances both internally and externally either through debt or equity and this is due to the challenges that small scale enterprises the encounter in their working capital management resulting from the nature of the cash flows and these has a huge effect on profitability (Mazzarol, et al... 2015). Small scale enterprises have also failed to find a reliable type of financing to support their businesses which would remain profitable for a longer period of time therefore resulting in to changing their business strategies to meet the customers demand (Getahun, 2016). These could result from cost of capital where they are charged higher interest on the loans acquired and credit rationing as a result of collateral shortage. The adoption of careless financial management practices are some of the causes of small scale business failures and this would arise in a fall in profit (Agyei-Mensah, 2011). The success or failures of small scale business firms is associated with financial stability or viability. A poor financial management practice greatly affects the profitability of the firms which reflects on its performance (Getahun, 2016).

The effectiveness and efficiency of any financial management practice is based on the foundation which is focused on the goals of the business enterprise which are compared and evaluated upon.(Oladipo and Okafor, 2013) opine that most organizations are adopting new financial management systems in order to improve on the organizations performances; however, there are still cases of weak financial systems and procedures which reduces profitability and small business enterprises in Kabale municipality are not exceptional. The expectations of better returns, business owners and firms continue to involve in huge investments while a good number of these businesses continues to make losses annually (Ndayanale, 2013). Improper financial management practices and structures over a considerable time have cost most firms which consequently affects profitability. (Nikolic et al...,2019) posits that concerned stakeholders ought to improve on the conditions which Small scale enterprises operate thereby removing the factors that hinder the growth of small scale entrepreneurs by developing a supportive system to operate their businesses. The purpose of the study was to examine how financial Management Practices affect profitability amongst small scale enterprises. The study was motivated by the following objectives: to establish the factors affecting profitability of small scale enterprises in Kabale municipality, to determine the effects of financial management practices on profitability amongst the small scale enterprises in Kabale Municipality and to assess the relationships between financial management practices and profitability amongst business firms in Kabale Municipality

\section{Hypothesis}

1. Efficient financial management practices does not affect profits in small business enterprises.

2. An effective working capital management practice does affect profits of small business enterprises.

3. There is no significant relationship between cash management and profitability of small business enterprise. 


\section{Literature Review}

\section{Theoretical framework}

The study was build on Managerial Efficiency Theory of Profits, which assumes that firms that efficiently manage productive operations successfully meet their customers' needs. Firms that demonstrate high managerial skills and production efficiency are compensated with above-normal profits (Sanyal, 2019). When management opts to change her operations, such as those that reduce the cost of operating business, product development, pricing structure, market models, they will undoubtedly enhance their profits.

\section{Theoretical framework}

The study builds on the innovation theory, which was propagated by Joseph Schumpeter in 1934. The theory assumes that innovation is the reason behind growth and fluctuations in business investments (Megha, 2016). Schumpeter uses the concept of 'innovation' to connote policy measures that reduce costs of production or increase demand for products (Sanyal, 2019). Therefore, economic profits come as a reward to the entrepreneur for his innovations that result in cost falls or increased sales at a better price (Knowledgiate Team, 2017). Cantwell (2001) adds some light on Schumpeter's view of innovation. Innovation does not mean the temporary profits enjoyed in monopolistic markets by first movers but the ability of a firm to experiment with new technologies to solve problems that may associate to increased costs of production or affect sales volume. The point addressed here is that entrepreneurs should remain innovative since other players in the market are likely to copy the same innovations to their advantages, which affects the profits of the original innovator. Knowledgiate Team (2017) criticizes the theory on two grounds: the theory concentrates on innovations for occuring profits, which ignores several other factors that influence profits, such as financial management practices. The same criticism was raised by (Kaya, 2015) who posits that innovation is a multiplicity of actors, economic and non-economic in a society. Therefore, the entrepreneur ought to be dynamic in all economic development endeavors. The theory views the entrepreneur as merely an innovator yet he is responsible for other functions of the organizations such as financial management. To this, (Sweezy, 1943) adds that the entrepreneur must overcome the pyschological and social resistances that come by when attempting to do new things. In esssence, the author suggests that whether the entrepreneur is the innovator or not, he must exercise leadership potentials towards economic channels. The current study uses the innovation theory to link financial management practices to profitability in small and medium enterprises. Financial management practices are actions of innovation, aimed at reducing the costs of producing goods and services while increasing demand for these good and services.

\section{Financial Management practices}

(Kilonzo and Ouma, 2015) defines financial management practices (FMP) as management of funds and how these funds are put to use in achieving organizational objectives and maximization of share holders value. FMP is significant in supporting the diversification of service and product lines and these helps in 
planning for the growth of the business. Financial management shows the right direction for the future growth of the business by determining how to increase the market value of products and services which results to the economic growth of a country.FMP may include working capital management, capital structure, financial reporting mechanisms, capital budgeting and others.(Lavia-lopez and Hiebl , 2014) states that efficient financial reporting systems are significant in determining the growth and survival of small scale enterprises.(Musah, 2017) establishes that working capital management (WCM) is significant in making rightful decisions related to financial management which has a critical impact on the financial performance of a business enterprise. Capital structure represents the right capital mix of either debt or equity which enables financing business operations (Mazzarol et al... 2015).Companies should adopt optimal financial decisions aimed at increasing the financial performance of their firms and also adopt financial management practices that support the growth of their firms in expanding market share and profits (Muguchia, 2018). Similarly, (Marus Eton et al..., 2020) posits that there is need for business firms to align their business operations to the best financial management practices and train their staff on the internal control activities that ensure adherence to the principles of accounting and financial records. (Yohanes et al.., 2018) argues that an effective financial management practice may lead to expansion of businesses, success and profit making by small scale enterprises'. These financial management practices rotate in the allocation of resources, procurement and cash budgeting by small scale entrepreneurs. It's significant for small scale enterprises to ensure that they have adequate and constant supply of financial resources to run their activities in order to get good returns. An established financial management practices supports managers to understand the financial position of a firm at a certain point in time and helps in forecasting the future financial need and trends (Muhozi and Mulyungi , 2018).

Today's business firms are faced with the challenges of adopting the best financial management practices which affects financial stability of a firm.(Lakew and Rao, 2014) posits that inefficient FMPs coupled with unpredictable and harsh environment where businesses are operating often leads to huge challenges to the small scale enterprise. (Muneer et al.., 2017) opines that small scale enterprises have inefficient accounting and financial management systems which are completely different from the ones large companies have adopted. Inefficient and poor cash management system puts the business operators in a precarious situation especially when the customers are not satisfied with the services being offered and this may lead to a shift to the next service provider which affects profitability (Festus, 2011).Efficient and effective financial management practice is the base upon which financial manager's use in tracking the financial success of an organization and the shareholders value (Maduekwe and Kamala, 2016). Firms should maintain an effective and efficient working capital as a policy and they should know how much of the working capital that ought to be maintained for daily operations of the firm (Sarkar and Sarkar, 2013). Managers of business enterprises and finance managers should therefore enforce adherence to cash policies put in place for purposes of guidance and managing cash (Kakeeto et al..,2017)

Cash management is an important practice as it embodies all payments and incomes during a particular period which are highlighted (Bobitan and Mioc , 2011). Optimum cash management is ideal in the sense that having too much cash may turn to be costly especially when one is paying interest on cash.(Mbroh, 
2012) argues that efficient cash management system prevents bankruptcy while it increases business sustainability and profitability. Cash flows management is significant especially where accessibility of cash is seen to be exorbitant and difficult. These may be in a period where the economy could have slipped into recession and most businesses would be facing risk as most customers are facing financial difficulties in meeting their obligations. (Eton et al.., 2019) argue that there is need for business owners to consider hiring business experts who could use different statistical models to forecast business performance.

\section{Profitability}

(Tauringana and Afrifa, 2013) defines profitability as an organizations ability to earn financial profit and gain. (Oladipupo and Okfor, 2013) posit that a firm's net profit is determined by difference between revenue gained during a particular financial period and the enterprise operating expenses during a period of business operations. Profitability is the determinant of the growth, success and sustainability of any business venture (Onwumere et al.., 2012).Profit is a major objective of financial management which is wealth maximization (Malik et al.., 2011). Business enterprises that are not profitable do not survive for long in a highly competitive market. A business enterprise that is not generating revenue or profits does not survive in a hostile market (Eton et al., 2017).Firms should have businesses that are profitable and can sustain themselves in the market even under hostile conditions, (Adebayo and Onyeiwu,2018). In understanding the development and effective growth strategy of a firm and its position in the market is determined through its profitability (Al-Mwalla, 2012). Profit making is fundamental in survival of a business where as growth is seen as a key to long-term success and profitability in a business(Abuzayed, 2012). The growth and success of any business enterprise is determined on the ability of the business enterprise to always be making profit even if it's facing any financial difficulties the a particular period. (Oladipupo and Okafor, 2013) establishes that it's imperative for the business enterprise to assess the drivers that may enhance the business profitability if the firm expects to achieve the profitability goal of the business enterprise.(Moore et al.., 2010) argue that small business enterprises assume that higher revenues may result into higher profit margins and fail in realizing that if physical cash isn't obtained from those revenues, business enterprises would end up with insufficient cash to meet its expenses and thus face challenges in managing its liquidity.

The adoption of various cost control methods such as cash flow management, standard costing and proper budget management system controls higher costs that business enterprises may likely incur at the same level of income where expenses are lower may result in increase of profitability (Kumar and Shafabi, 2011). Cash flow management in a business enterprise is significant in planning for the unforeseen, profitability and business sustainability which all business strives for (Patel, 2010). Most businesses argue that credit sales, increase in cash and inventory may lead to increased business profitability. (Syafri, 2012) urges that the composition of assets and the quality of loans that a business enterprise acquire would definitely affect the business profitability. Profitability of a business enterprise indicates how a business firms is in a position to generate income for a period of time from stock, assets and sales return. (Farah and Nina, 2016) establishes that productivity level and firms size are very strong 
determinant of profitability. It's important to note that in conducting any business, finance managers ought to develop an effective profit strategy for their businesses (Gitman and Zutter, 2012).Profitability may be considered an important precursor to enterprise success and that most successful businesses do not suffer from the tradeoffs implied theory (Aron and Andrew, 2015).

Firm's profitability may be grossly affected by inadequate funds that meet the operating costs and capital expenditure, mismanagement of fund and poor management of funds can greatly affect profitability (Pais and Gama, 2015).Inadequate capital, poor financial planning at your disposal, inadequate ability to match with the expected growth of the business enterprise and poor business forecast are some of the reasons affecting profitability which leads to businesses failure (Salazar, 2012). Profitability of any business enterprise is affected mostly as a result of liquidity and returns on assets invested by a business firm (Mmbaya, 2013).A study to determine the financial factors that affect profitability of SMEs by (Popa \& Ciobanu, 2014) found managerial decision on investment to be key, in influencing profitability. The study established that managerial decisions on investment during inflation, unemployment, economic crises and changes in GDP are very important.(Asare \& Angmor ,2015) used short-term loan, long-term loan and trade credit to measure the effect of debt finance on profitability. The findings indicate that short-term loan has a significant negative relationship between return on assets and profit margin ratio. Firms would always need thorough training and skills acquisition to better utilize their loans. New loans tend to constrain profitability among start-ups than older Loans (Banarjee, 2014). While this study suggests a link between financial constraints and growth, it lacks quantitative data on firm activity. Small Scale Enterprises that encounter multiple effects against their profitability are expected to have retarded growth levels. However, (Fitzsimmons, Steffens, \& Douglas, 2005)found no evidence between growth and profitability. The authors established that growth rates are volatile over time and therefore, exhibiting a non-linear relationship. Examining the factors affecting profitability, (Margaretha \& Supartika, 2016) found productivity and industry affiliation to positively influence profitability. Much as the authors recommend firm managers to design business strategies that focus on productivity, they do not show how these two variables affect profitability. In line with industrial affiliation, firms that involve in foreign trading enjoy higher profitability (Prijadi \& Desiana, 2017). However, particular drive to profitability is evident among firms with optimal working capital. Small Scale Enterprises with liquidity show higher profitability than large wholesale and retail companies (Mijic, Nuseva, \& Jaksic, 2018). (Nyambane and Ouma, 2017) posit that enterprises ought to establish liquidity management policies which would reduce risk for business failure and thus increase profitability. This policy procedure may uphold low cash conversion cycle.

\section{Financial Management Practices and Profitability}

(Zubair and Muhammad, 2013) argues that working capital management (WCM) is one of the determinants of profitability. It's therefore significant to note that WCM plays an important role in improving business profitability. WCM practices ensure that firms are in position to continuously operate with adequate cash flows to meet the short term debts and operational expenses that may fall due. WCM especially trade credit management and cash management has a positive relationship with profitability 
of small scale enterprises (Norah et al.., 2015). The owners of small scale enterprises should pay a lot of attention on the financial management practices due to the positive effects it has on the profitability of their business enterprises (Yensu et al.., 2016). WCM is a significant instrument of profitability and when done through effective control it will measure a firm performance (Chowdhury et al...., 2018). Efficient WCM sets the base to providing enough liquidity for daily operations of the firm as the fall due to leading generation of profits (Wingaroja and O'Neil, 2018). Finance managers ought to have good working capital management techniques in order to create value for their share holders and these would enhance good relationships between profitability and working capital measures in a hostile business environment. (Muhozi and Mulyungi, 2018) notes that having a comprehensive financial plan would improve on the organizations profitability, these would be as a result of proper management of financial transactions by the qualified financial managers in the company. Companies that manage its financial management practices well have constantly reported an improved financial performance. Inefficiency in the financial management practices of the organization may cause damages in business growth and would adversely affect the firm. However, efficient management of finances would steer the business to achieve its growth where as wrong financial decisions are always very costly to a firm and managers should try to avoid such. In order to ensure long term survival of a business enterprise, business managers ought to have efficient and timely financial reporting, up to date accounting information system and adequate working capital so as to gain profits in the sector, (Yohanes et al.., 2018). Financial management practices are very crucial for the well being of business enterprises, survival and profitability (Lakew and Rao, 2014). FMP's are majorly focused on profitability, liquidity, market values of the business and investment.

The harmonization of cash management practices such as cash payment and cash receipts are key for the enhancement of profitability in an organization (Uwuigbe et al..., 2012).Many business managers do not put much emphasis in cash flow which is a mistake as these managers confuse profits made from the business with the cash flows of the business (All Africa.com, 2013). The adoption of a liberal and a flexible credit policy by business enterprises would most likely increase sales and results into profit increase, but it may also lead to a risk of bad debt (Vijayakumar, 2011), however using a credit policy which is strict may result into increase in liquidity and security that reduces profitability (Akoto et al....., 2013). The ability to manage credit sales effectively may lead to building trust between the business enterprise and suppliers that leads into a long term business relationship and profit increase (Mbawuni et al.., 2014). The significance of effective and efficient credit management is based on a business operations methodology (Enow and Kamala, 2016).Profitability is noted to be positively influenced by credit management, cash management and debtor management (Nzitunga, 2019).Small scale entrepreneurs ought to adopt optimal WCM at which profitability is at its maximum (Afrifa and Padachi , 2016).

(Ali, 2019) urges that FMP had shown a significant improvement in the financial performance in the service companies. The company's capability keeps on improving in the investment decision and working capital management. (Eton et al..., 2018) posits that business firms ought to devote time and more resources in equipping themselves and their employees with the basic financial management skills and knowledge to embrace business sustainability. Financial management skills should be conducted for 
small scale entrepreneurs in a bid to sharpen their financial skills with a purpose of improving on their daily operations (Bismark et al..., 2018). The ability of having the right finances injected into business and plan it effectively can support the firm's growth and profitability. (Nyambane and Ouma , 2017) posits that while the business enterprises strives to meet its current obligations, the usage of cash balances would be ideal while investing the surplus cash in a better way that increases their levels of income.

\section{Methodology}

The study adopted a descriptive and correlational research designs. Descriptive research design is adopted when the study aims at portraying particular characteristics and nature of a given phenomenon. The descriptive design clearly brought out the limiting factors affecting profitability of Small Scale Enterprises in Kabale municipality. Descriptive statistics supports the description of data in a simplest way, organize the data very well and summarizes it well (Cooper and Schindler, 2014). The study used correlation design to test the relationships between working capital and profitability, and cash management and profitability. The study used both quantitative and qualitative approaches. The study was conducted in Kabale Municipality and targeted 390 small scale business units, which was estimated from approximately 15,600 small scale businesses (UNBS, 2018). The study adopted various sampling techniques like purposive, simple random sampling and stratified sampling amongst the sectors considered which included trade, service, urban agriculture, construction and horticulture. Stratified sampling techniques were used in selecting trade and service sector, dividing the study population into strata indicates a proportionate representation of the sample (Saunders et al.., 2016). In determining the sample size for construction sector the study used purposive sampling while urban agriculture and horticulture sector simple random sampling technique was used in choosing the small business enterprises within Kabale municipality.

The sample size was determined using Yamane (1967)

$$
n=\frac{N}{1+N e^{2}}=\frac{15,600}{1+0.05 \times 0.05 \times 15600} \approx 390
$$

Where $n=$ Sample size required for the study

$\mathrm{N}=$ Total Population

$\mathrm{e}=$ Level of precision

Primary and secondary data collection methods were used. The questionnaire was used as a primary method of data collection and it was a structured questionnaire with close-ended questions. The usage of questionnaire helps the researcher to save time and supports the collection of larger amount of information (Christensen et al.., 2014). The items in this instrument were gleaned from literature review. The instrument had four sections: background, financial management practices, profitability, and factors affecting profitability. Items in the background section were constructed on nominal and ordinal scales 
while items on basic sections were constructed on interval scale, particularly a five-point likert scale. This method of data collection was used to make the project feasible but also reduce time and costs of data management and analysis. The study collected quantitative data to realize the set objectives (Stoudat, 2014; Creswell, 2014). The study used multiple regression analysis to determine the linear effect of financial management practices on profitability. (Creswell, 2012) argues that adopting multiple regression techniques provides estimates of the relationship between a single dependent variable and several independent predictor variable and the study adopted the multiple regression model in order to determine the parameter estimate to attain a fitted multiple regression model which may provide a basis for hypothesis testing.

\section{Table 1: Reliability Statistics}

\begin{tabular}{|llll|}
\hline Variable & $\begin{array}{l}\text { Cronbach's } \\
\text { Alpha }\end{array}$ & $\begin{array}{l}\text { Cronbach's Alpha Based on Standardized } \\
\text { Items }\end{array}$ & $\begin{array}{l}\text { N of } \\
\text { Items }\end{array}$ \\
\hline Profitability & .844 & .842 & 9 \\
\hline Working capital & .771 & .776 & 8 \\
\hline $\begin{array}{l}\text { Cash } \\
\text { management }\end{array}$ & .805 & .811 & 10 \\
\hline
\end{tabular}

\section{Source: Field data, 2020}

The pretest of the instrument was conducted among isolated small scale businesses on the outskirts of Kabale municipality. The instrument indicated Cronbach's alpha coefficients of above 0.7 , for all the variables. (Warrens, 2014) argues that Cronbach's alpha is taken as the most common coefficient in approximating reliability test scores for a structured questionnaire and determining consistency internally. This suggests that the instrument used in this study was internally stable and the results are adequate for conclusion and generalizability.

\section{Results}

\section{Background characteristics}

In terms of participants' background characteristics, there weren't significant differences observed in participation according to gender since $52.8 \%$ were male and $47.2 \%$ were female. The existence of many women in business is proactive movement by the government of Ugandan to socially and economically empower women. a greater percentage of the business owners who took part in the study were adults $(52.8 \%)$ followed by the youths (36.2\%). Least participation among the adults was due to unwillingness to take part in the study. Otherwise, there a many businesses in Kabale operated by adult entrepreneurs. The distribution according to the highest education level, $88.3 \%$ did not have university education. This might raise questions on their ability to implement financial management practices. Despite the low 
education of most of the participants, $81.0 \%$ had operated their businesses for less than 10 years, and were surviving, mostly of whom are in service businesses (33.1\%) and horticulture (26.4\%).

\section{Factors affecting profitability}

The researcher raised a number of factors assumed to affect profitability of businesses in Kabale municipality. Figure 1 presents the summary.

Our results reveal a three categories of the factors affecting businesses in Kabale. The first category relates operational costs. These appeared to be the key among the factors affecting profitability, where $36.2 \%$ indicated level of fixed costs, and $23.9 \%$ indicated costs of production. The second category relates to microeconomic factors, such as price discrimination (13.5\%), level of economic growth (9.8\%) and number of substitutes (8.0\%). The third category relates to personal characteristics of the business, such as marketing strategies (2.5\%) and managerial competencies (1.8\%). Overall the research observed that operational costs exert the greatest influence on profitability levels among small scale businesses in Kabale municipality.

\section{Financial management practices and profitability}

The researcher used multiple regression to establish the effect of financial management practices on profitability. Multiple regression model is used when the independent variable is a set of predictors, and there is need to determine the effect of each independent variable on the dependent. In this study, financial management practices constituted working capital and cash management. These were tested against profitability.

\section{Table 2: Regression coefficients}




\begin{tabular}{|llllll|}
\hline Model & $\begin{array}{l}\text { Unstandardized } \\
\text { Coefficients }\end{array}$ & \multicolumn{3}{l|}{$\begin{array}{l}\text { Standardized } \\
\text { Coefficients }\end{array}$} \\
& B & $\begin{array}{l}\text { Std. } \\
\text { Error }\end{array}$ & Beta & t & Sig. \\
\hline (Constant) & 0.202 & 0.258 & & 0.781 & 0.436 \\
\hline Working Capital & 0.830 & 0.077 & 0.724 & 10.794 & 0.000 \\
\hline Cash Management & 0.100 & 0.087 & 0.077 & 1.144 & 0.254 \\
\hline R & 0.777 & & & & \\
\hline R Square & 0.604 & & & & \\
\hline Adjusted R Square & 0.599 & & & & \\
\hline $\begin{array}{l}\text { Std. Error of the } \\
\text { Estimate }\end{array}$ & 0.452 & & & & \\
\hline $\begin{array}{l}\text { Regression sum of } \\
\text { squares }\end{array}$ & 49.944 & & & & \\
\hline $\begin{array}{l}\text { Residual sum of } \\
\text { squares }\end{array}$ & 32.713 & & & & \\
\hline Total & 82.657 & & & & \\
\hline
\end{tabular}

Predictors: (Constant), Cash Management, Working Capital

Dependent Variable: Profitability

According to (R Square $=.604)$, the study observed that financial management practices account for about $60.4 \%$ of the variations in profitability. Assuming the sample to be representative enough, financial management significantly affects profitability of SMEs in Kabale municipality Individual effect of financial management practices were presented by beta coefficients. Precisely, $(B=.830 ;$ sig $=.000<.05)$ shows that a variation in working capital by one-unit is likely to account for $83.0 \%$ variations in profitability. The significant value, which is less than 0.05 imply that working capital management has a significant effect on profitability. Similarly, $(B=.100 ;$ sig. $=.254>05)$ shows that a variation in cash management by one-unit is likely to vary profitability by $25.4 \%$. However, the significant value, which above 0.05 shows that cash management is not statistically significant in accounting for the variations in profitability. The regression of sum of squares (49.944) which are greater than the residual sum of square (32.713), which implies that profitability has a good role in explaining variations in profitability in Kabale municipality.

To test for the relationships between financial management practices and profitability, the study adopted correlation tests. Correlation measures use the correlation coefficient, which ranges from 0.0 to 1.0 to measure the strength between two numerical variables. The direction of the relationship can be positive 
or negative. Positive relationships suggest a variation in the same direction for both variables while a negative relationship suggests a variation in opposite direction for the two variables.

\section{Table 3: Correlations}

\begin{tabular}{|c|c|c|c|c|}
\hline Variable list & & Profitability & Working Capital & Cash Management \\
\hline \multirow[t]{3}{*}{ Profitability } & Pearson Correlation & 1 & $.775(\star \star)$ & $.562(\star \star)$ \\
\hline & Sig. (2-tailed) & & .000 & .000 \\
\hline & $\mathrm{N}$ & 163 & 163 & 163 \\
\hline \multirow[t]{3}{*}{ Working Capital } & Pearson Correlation & $.775(\star \star)$ & 1 & $.671(\star \star)$ \\
\hline & Sig. (2-tailed) & .000 & & .000 \\
\hline & $\mathrm{N}$ & 163 & 163 & 163 \\
\hline \multirow[t]{3}{*}{ Cash Management } & Pearson Correlation & $.562(\star \star)$ & $.671(\star *)$ & 1 \\
\hline & Sig. (2-tailed) & .000 & .000 & \\
\hline & $\mathrm{N}$ & 163 & 163 & 163 \\
\hline
\end{tabular}

** Correlation is significant at the 0.01 level (2-tailed).

From the correlation table, this study observed a very strong relationship $(r=.775 ; p$-value $=.000)$ between working capital management and profitability. This implies that a variation in working capital is associated to a positive and strong variation in profitability. Similarly, the study observed a strong relationship $(r=.562$; $p$-value $=.000)$ between cash management and profitability. This implies that a variation in cash management is associated to a positive and moderate variation in profitability.

\section{Hypothesis testing}

The study used chi-square statistics to test hypotheses. Chi-square is the statistical test that helps in ascertaining whether there is an association between two variables. The study used chi-square statistics under the cross tabulation procedure. For purposes of interpretation, if the (asymptotic significance $<.5$ ) there is an association otherwise there is no association.

\section{Table 4: Chi-Square Tests for Financial management practices and profitability}




\begin{tabular}{|llll|}
\hline & Value & df & Asymp. Sig. (2-sided) \\
\hline Pearson Chi-Square & $4529.424^{\mathrm{a}}$ & 2912 & .000 \\
\hline Likelihood Ratio & 976.793 & 2912 & 1.000 \\
\hline Linear-by-Linear Association & 146.201 & 1 & .000 \\
\hline N of Valid Cases & 163 & & \\
\hline
\end{tabular}

The study set $\mathrm{HO}:=$ Null hypothesis, and HA: = Alternative hypothesis. $\mathrm{HO}$ : Efficient financial management practices does not affect profits in small business enterprises; HA: Efficient financial management practices affects profits in small business enterprises.

Source: Field data (2020).

The study found (asymp. Sig. <.05). Therefore the researcher rejected the null hypothesis, accepting the alternative hypothesis that efficient financial management practices affects profits in small business enterprises.

Table 5: Chi-Square Tests for working capital and profitability

\begin{tabular}{|llll|}
\hline & Value & df & Asymp. Sig. (2-sided) \\
\hline Pearson Chi-Square & $1049.763(\mathrm{a})$ & 616 & .000 \\
\hline Likelihood Ratio & 434.297 & 616 & 1.000 \\
\hline Linear-by-Linear Association & 97.361 & 1 & .000 \\
\hline N of Valid Cases & 163 & & \\
\hline
\end{tabular}

The study set $\mathrm{HO}_{1}=$ Null hypothesis; $\mathrm{HA}_{1}$ = Alterative hypothesis. $\mathrm{HO}_{1}$ : An effective working capital management practice affect profits of small business enterprises. $\mathrm{HA}_{1}$ : An effective working capital management practice affects profits of small business enterprises.

The study established (asymp. Sig. <.05). Therefore the researcher rejected the null hypothesis, and accepted the alternative hypothesis that an efficient working capital management practice affects profits in small business enterprises.

Table 6: Chi-Square Tests for cash management and profitability 


\begin{tabular}{|llll|}
\hline & Value & Df & Asymp. Sig. (2-sided) \\
\hline Pearson Chi-Square & $1177.721(\mathrm{a})$ & 672 & .000 \\
\hline Likelihood Ratio & 382.603 & 672 & 1.000 \\
\hline Linear-by-Linear Association & 51.200 & 1 & .000 \\
\hline N of Valid Cases & 163 & & \\
\hline
\end{tabular}

The study set $\mathrm{HO}_{2}=$ Null hypothesis; $\mathrm{HA}_{2}=$ Alterative hypothesis. $\mathrm{HO}_{2}$ :There is no significant relationship between cash management and profitability of small business enterprise. $\mathrm{HA}_{2}$ : there is a significant relationship between cash management and profitability of small business enterprises.

The study observed that (asymp. Sig. < .05). Therefore the researcher rejected the null hypothesis, and accepted the alternative hypothesis that there is a significant relationship between cash management and profitability of small business enterprises.

\section{Discussion}

The study established the factors that affect profitability of small enterprises in Kabale Municipality. Evidence shows triad of factors affecting small enterprises: operational costs, microeconomic, and managerial factors. Operational costs pointed mostly to fixed and production costs. In the context of operational costs, the findings are in agreement with (Kumar and Shafabi, 2011) who posited that firms that implement cost control strategies like cash management, standard costing, and budget implementation systems lower their expenses while increasing their profits. In this view, firms in Kabale that implement some form of cost control are likely to register inverse relationships between operational costs and profit levels. (Pais and Gama, 2015) also posited that firms that do not have adequate funds to meet their operational costs experience gross effects in their profitability. The consistency of these studies with the current findings add relevancy to the practice of profitability of small enterprises.

The study determined the effect of financial management practices on profitability of business enterprises. Evidence shows a significant effect of financial management practices on profitability. Assuming our sample to be representative of all small business enterprises in Kabale municipality, $60.4 \%$ of the firms are likely to register increasing profitability due to prudent financial management practices. The findings agree with (Muhozi and Mulyungi, 2018; Yohanes et al..,, 2018) who noted that firms with comprehensive financial plans and judicious financial management practices improve their profitability. They contend that financial plans promote proper management of financial transactions, but should performed by competent financial managers. Importantly however, the very nature of most of the small business enterprises in Kabale municipality may not allow them to employ professional financial managers. This view agrees with (Africa.com) which reports that most managers of small business enterprises confuse profits and cash flow. The report confirms that many business managers least 
emphasize cash flow. They fail to harmonize flexible credit policy with profitability thereby increasing risks of bad debts.

The study assessed the relationships between financial management practices and profitability. Actually, the findings, which showed a significant strong relationship between financial practices and profitability support (Prijadi \& Desiana, 2017) who established a relationship between involvement in foreign trade and profitability. Similar results by (Mijic, Nuseva, \& Jaksic, 2018) show a positive relationship between liquidity and profitability. The findings, which revealed that financial management practices are positively related to profitability disagree with Asare \& Angmor (2015) who established a negative relationship between return on assets and profit margin ratio. The results of this study also disagree with (Fitzsimmons, Steffens, \& Douglas, 2005) who found no evidence between growth and profitability of small business enterprises. They argued it from the view point that growth rates of firms vary with time, and therefore exhibit a non-linear relationship.

\section{Theoretical And Practical Implications}

This study assumed a representative sample of the small business enterprises in Kabale municipality. Therefore, small business firms should ensure sound financial management practices in order to experience positive changes in their profitability levels. Particularly however, small business owners must pay a lot of attention to their working capital dynamics, which highly affect their profitability levels. Similarly, small business owners should observe proper cash management as this also influences positive changes in their profitability levels. Small business owners should endeavor to hire professional financial managers to provide technical prediction of their financial performance, and profitability in particular. Financial management practices such as budget control, working capital management, cash management, financial forecasting and analysis require professionals to provide expert decision and judgment, which most small businesses lack. To the researchers, this study provides empirical evidence on the contribution of the innovation theory and managerial efficiency theory of profits to management of operational and production costs in business. The theory can be applied to understand the operations of small business enterprises in developing economies like Uganda.

\section{Conclusion}

The study examined financial management practices and profitability of small scale enterprises in Kabale municipality Uganda. The study established a significant influence of financial management practices on profitability. Evidence shows some seasoned financial management practices, especially working capital and cash management practices, all of which indicate strong associations with profitability. However, the impediments to increased profitability roam beyond financial management practices. This study established a triad-factor that limits profitability, characterizing operational costs, microeconomic, and personal characteristics. Notably to the researchers is the gulf, which operational costs expose to business profitability. As business owners work to introduce more financial management practices in their businesses (financial forecasting, budget controls, and analysis), they should consider 
cost-cutting practices to balance profitability and operational costs. It can be concluded that efforts to strengthen personnel characteristics might be of lesser value to increasing profitability as compared to management of operation costs. Therefore, hiring professionals and experts in financial management is highly recommended, though the scale of engaging them at small scale level in Kabale municipality, and Uganda as a whole is still low.

\section{Areas For Future Research}

There should be a comprehensive study on cost management and profitability, moderated by managerial competencies among Small Scale Enterprises in Uganda.

\section{Abbreviations}

FMP Financial management practices, OECD Organization for economic cooperation and development, WCM working Capital management, UNBS Uganda national bureau of standard

\section{Declarations}

\section{Acknowledgement}

Not applicable

\section{Author information}

Dr. Marus Eton $(\mathrm{PhD})$ is a senior lecturer in the Faculty of Economics and management Sciences at Kabale University, Uganda, Fabian Mwosi is a lecturer at Bishop Barham University College Kabale, Uganda, Dr. Eliab Byamukama Mpora (PhD) is a lecturer at the Faculty of economics and management sciences, Kabale University, Uganda, Dr. Bernard Patrick Ogwel (PhD) is at lecturer at Kampala International University, Kampala Uganda.

\section{Author Contribution}

All authors contributed adequately in this work

\section{Funding}

No funding was received for this research

\section{Data availability}

Data sharing is not applicable to this paper. Any datasets analyzed or generated are contained in the paper.

\section{Competing Interest}


The authors declare that they have no competing interest.

\section{Compliance with Ethical Standards'}

This article does not contain any studies with human participants or any animals performed by any of the authors.

\section{Informed Consent}

Not applicable

\section{References}

1. Abuzayed, B. (2012). Working capital management practices and firm performance in emerging markets: The case of Jordan, International Journal of Managerial Finance, Emerald Group Publishing 8(2), 155-179 www.emraldinsight.com/1743-9132.htm

2. Adebayo I. S \& Onyeiwu, C. (2018). The determinants of profitability of manufacturing firms in Nigeria. International Journal of Economics, Commerce and Management Vol. 6(4) pp 479-493 http://ijecm.co.uk/

3. Afrifa, G.A., \& Padachi, K. (2016). Working Capital Level influence on SME profitability. Journal of Small Business and Enterprise Development, Vol. 23 No. 1, pp. 44-63 https://doi.org/10.1108/JSBED01-2014-0014

4. Agyei-Mensah. K. B. (2011). Financial Management Practices of Small Firms in Ghana: An Empirical Study. African Journal of Business Management Vol. 5(10), pp 3781-3793 http://dx.doi.org/10.2139/ssrn.1597243

5. Akoto, R. K., Awunyo, V.D., \& Angmor. P. L. (2013). Working Capital Management practices and Profitability: Evidence from Ghanaian listed manufacturing firms. Journal of economics and international finance, 5(9), 373-379 http://www.academicjournals.org/JEIF

6. Ali, A. Y. S. \& Isak. A. O (2019). Financial Management Practices and Financial Performance of Service Companies in Somalia. Research Journal of Finance and Accounting Vol.10, (4) pp 59-68 www.iiste.org

7. All Africa.com (2013). Small business cash flow management.(Online) Available: http://search.proquest.com/docview/135373019(Accessed 18 April 2014)

8. Al-Mwalla, M. (2012). The impact of working Capital management practices on firms profitability and value: The case of Jordan. International Research Journal of Finance and Economics, 85, 147-153

9. Aron. P., \& Andrew. Y. (2015). Testing relationships between firm size and perceptions of growth and profitability: An investigation into the practices of Australian ICT SMEs. Journal of Management and Organization 22:5 pp. 680-701

10. Asare, C., \& Angmor, P. L. (2015). The effect of debt financing on the profitability of SMEs in Accra Metropolis. ADRRI Journal of Arts and Social Sciences, 13(2(2)), 1-11. 
11. Banarjee, R. (2014). SMEs. Financial constraints and growth. BIS Working Papers. No 475. Bank of International Settlement.

12. Bismark, O., Kofi. A-G, F., Kofi. O.A., Eric. H.(2018). Impact of Financial management Practices on the Growth of Small and Medium Scale Enterprises in Ghana: The Case of Birim Central Municipality. International Journal of Innovation and Research in Educational Sciences 5(2) pp 177-184

13. Bobitan, N., \& Mioc, A.D. (2011). Using information on the cash flow situation in substantiating entities' decision. Agricultural Management (Online), 13(3):299-306

14. Cantwell, J. (2001). Innovation, profits and growth: Schumpeter and Penrose. United Kingdom: Henley Business School.

15. Chowdhury A. Y., Alam, M.Z., Sultana S., \& Hamid M.K. (2018). Impact of working Capital Management on Profitability: A case study of pharmaceutical Companies of Bangladesh. Journal of Economics, Business and management, Vol. 6(1) pp 27-35 http://www.joebm.com

16. Chrietensen, L. B., Johnson, R.B., \& Turner, L. A (2014) Research Methods, Design and Analysis (11 ${ }^{\text {th }}$ ed.) Harlow: Pearson Education Limited.

17. Cooper, D.R., \& Schindler, P.S (2014). Business Research Methods (12 $2^{\text {th }}$ ed.) New York: McGraw Hill.

18. Creswell, J.W. (2014). Research design: Qualitative, quantitative and mixed methods approach $\left(4^{\text {th }}\right.$ ed) Los Angeles: Sage

19. Derbie, M., \& Kassahun, T. (2013). Deterrents to the success of Micro and Small Enterprises in AkakiKality Sub-City, (JBAS) Vol.5 (No.2) pp.1-33

https://opendocs.ids.ac.uk/opendocs/handle/20.500.12413/8836

20. Enow, S.T., \& Kamala, P. (2016). The accounts payable management practices of small, medium and micro enterprises in the cape metropolis, South Africa. Investment management and financial innovations, 13(1), 77-83 http://dx.doi.org/10.21511/imfi.13(1).2016.07

21. Eton, M., Uwonda. G., Mwosi, F., Ogwel. B. P., \& Obote, D. (2019). Cash Management and financial Performance of Business firms in Northern Uganda a Case of Lira District. International Journal of Business management and Technology. 3(4) pp. 115-125 www.theijbmt.com

22. Eton.M.,Mwosi.F., Mutesigensi. D.,\& Ebong. C.D. (2018). The role of financial Management in Supporting firms growth in Uganda, the case of West Nile Region. SSRG International Journal of Economics Management studies (SSRG-IJEMS) 5(4) pp. 1-9

23. Eton.M., Mwosi.F., Kaaya S., Ogwel. B.P \& Ahabwe. E. (2020). Internal Control System, Working Capital Management and Financial Performance of Private Institutions in Uganda: An Empirical Study in Mbarara District. International Journal of Research in Engineering, IT and Social Sciences. 10(3) http://indusedu.org

24. Farah. M., \& Nina. S. (2016). Factors affecting profitability of small medium enterprises (SMEs) firms listed in Indonesia Stock exchange .Journal of Economics, Business and management, Vol. 4, No. 2 pp 132-137 http://www.joebm.com 
25. Festus, A. (2011). Cash Management and Growth of Small Scale Business in Ntungamo Market. College of Business (Doctoral Dissertation, MAKERERE UNIVERSITY)

26. Fitzsimmons, J. R., Steffens, P. R., \& Douglas, E. J. (2005). Growth and profitability in smal and medium sized Australian firms. Melbourne: AGSE Entrepreneurship Exchange.

27. Getahun, M. (2016). The Challenges and Prospects of Small Scale Enterprise in Ethiopia: A Survey of some selected small scale enterprises in Addis Ababa City. International Journal of Scientific and Research Publications, Vol.6 (5) pp. 617-626 www.ijsrp.org

28. Gitman. L. J., \&Zutter. C. J. (2012). Principles of Managerial Finance, $13^{\text {th }}$ ed., USA: Addision Wesle,

29. Kakeeto, F., Timbirimu, M., Kiizah, P., \& Osunsan, O.K. (2017). Cash management and Organizational Profitability in Gumutindo Coffee Cooperative Enterprise Limited (GCCE) Mbale District Uganda. Journal of Research in Business and management Vol. 5, Issue 5, pp: 33-40 www.Questjournals. Org

30. Kaya, P. H. (2015). Joseph A. Schumpeter's perspective on innovation. International Journal of Economics, Commerce and Management, 3(8), 25-37.

31. Khamis, A. (2016). SMEs are key engines of Gulf Corporation Council economic and job growth: BLOOVO.COM research Press release $12^{\text {th }}$ October 2016

32. Kilonzo, J.M., \& Ouma. (2015). Financial management practices on the growth of Small and Medium Enterprises: A case of manufacturing enterprises in Nairobi County, Kenya. IOSR Journal of Business and Management, 17(8), 65-77 www.iosrjournals.org

33. Knowledgiate Team. (2017, August 16). Finance and Economics. Retrieved from Knowledgiate: www.knowledgiate.com

34. Kumar,A., \& Shafabi, A. (2011). Strategic Cost Management- Suggested framework for $21^{\text {st }}$ Century. Journal of Business and Retail Management Research 5(2), pp. 20-32

35. Lakew, D.M., \& Rao, P.D. (2014). Effect of financial management practices and characteristics of profitability. A Study of business enterprises in jimma Town Ethiopia. Journal of Research in Commerce and Management, 65-70 https://www.semanticscholar.org

36. Lavia Lopez, O., \& Hiebl, M. R. (2014). Management Accounting in Small and medium sized enterprises: Current knowledge and avenues for further research. Journal of Management Accounting Research, 27(1), 81-119

37. Maduekwe, C. C., \& Kamala, P. (2016). Performance measurement by small and medium enterprises in Cape Metropolis, South Africa. Problems and Perspectives in management, 14(2), 46-55 DOI:10.21511/ppm.14(2).2016.5

38. Malok, M., Waseem, J. U., \& Kifayat, U. (2011). Working capital management and profitability analysis of firms of textile industry of Pakistan. Journal of management sciences 6(2), 155-165

39. Margaretha, F., \& Supartika, N. (2016). Factors affecting profitability of small medium enterprises (SMEs) firm listed in Indonesia Stock Exchange. Journal of Economics, Business and Management, 4(2), 133-137. 
40. Mazzarol, T., Rebound, S., \& Clark, D. (2015). The Financial management practices of small to medium enterprises. In Small enterprise Association of Australia and New Zealand $28^{\text {th }}$ Annual SEAANZ Conference proceedings, 1-3

41. Mbawuni, J., Mbawuni, M.H., \& Nimako, S.G. (2014). The impact of working capital management practices on profitability of petroleum retail firms: Empirical evidence from Ghana. International Journal of economics and finance, 8(6), 49-62.

42. Mbroh, J.K. (2012). Cash management practices of small business owners in the Cape coast Metropolitan Area of Ghana. Asian Economic and Financial Review 2(1):40-58

43. Megha, M. (2016, May 12). Economics. Retrieved from Business Jargons: https://businessjargons.com

44. Mijic, K., Nuseva, D., \& Jaksic, D. (2018). The determinats of SMEs profitability in the wholsale and retail secto in Siberia. TEME, XLI/(No. 1), 97-111.

45. Mmbaya, L.K. (2013). Financial performance of football clubs in Kenyan premier League. Unpublished.

46. Moore, J., William, P., \& Longernecker, J. (2010). Managing Small business: An entrepreneurial emphasis. $15^{\text {th }}$ ed. Australia: South-Western/Cengage Learning.

47. Muguchia, M, M., (2018). The effect of financial management practices on the financial performance of the Companies listed at Nairobi Securities Exchange. Masters dissertation, Nairobi University.

48. Muhozi. E., \& Mulyungi. P. (2018). Effect of financial management practices on profitability of Agricultural processing enterprises in Rwanda. International Journal of Science and Research (IJSR) Vol 7(10) pp 627-632 www.ijsr.net

49. Muneer, S., Ahmad, R. A. \& Ali, A. (2017). Impact of financial management practices on SMEs profitability with moderating role of agency cost. Information management and Business Review, 9(1), 23-30

50. Musah, A. (2017). Benefits and challenges of bookkeeping and accounting practices of SMEs and its effects on Growth and performance in Ghana. JABM journal of accounting- business and management, 24(2), 16-36. http://journal.stie-mce.ac.id

51. Ndayanale, E. (2013). Namibia Crawls to profitability. Master's thesis. University of Namibia, Windhoek, Namibia.

52. Nikolic. N., Jovanovic. I., Nikolic. D., Mihajlovic.,\& Schulte. P. (2019). Investigation of the factors influencing SME failures as a function of its prevention and fast recovery after failure. Entrepreneurship Research Journa/Vol. 9(3) pp1-21 https://ideas.repec.org

53. Norah, K., Mbabazize, M., \& Shukla, J. (2015). The effect of capital budgeting investment decision on organizational performance in Rwanda. A Case study of bahresa grain milling Rwanda Ltd. International Journal of Small Business and Entrepreneurship Research, Vol. 3(5) pp.100-132

54. Nyambane, D.O., \& Ouma, B.O. (2017). Cash Management and Profitability of cement Industries in Kenya. International Journal of Economic, Commerce and Management, United Kingdom Vol. 5, 
Issue 4. pp 546-559 http://ijecm.co.uk

55. Nzitunga. J. B. (2019). Impact of working capital management practices on profitability in stateOwned Enterprises (SOEs) Central African Republic (CAR) Management 2019, 9(2):37-47 http://journal.sapub.org/mm

56. OECD. (2017). Financing SMEs and Entrepreneurs 2017: An OECD Scoreboard .OECD. Organization for Economic Co-operation and Development (2017). Enhancing the contributions of SMEs in a global and digitalized economy. In meeting of the OECD council at Ministerial Level, Paris (Vol.7)

57. Oladipupo, A.O., \& Okafor, C.A. (2013). Relative contribution of working capital management practices to corporate profitability and dividend payout ratio. Evidence from Nigeria. International Journal of business and finance research, 3(2), 11-20

58. Onwumere. J. U. J., Ibe, I.G., \& Ugbam. O. C. (2012). The impact of working capital management practices on profitability of Nigerian Firms. A Preliminary investigation. European Journal of Business and Management, 4(15), 192-201

59. Pais, M.A., \& Gama, P.M. (2015). Working Capital Management and SMEs Profitability. Portuguese evidence. International Journal of Managerial Finance, 11(3), 341-358.

60. Patel, U. (2010). Cash Management at Indian Oil Corporation Ltd. Masters in business administration, Dr. D.YPatil University

61. Popa, A.-E., \& Ciobanu, R. (2014). The financial factors that influence the profitability of SMEs. International Journal of Research in Economics and Management Sciences, 3(4), 177-185.

62. Prijadi, R., \& Desiana, P. M. (2017). Factors affecting the profitability and growth of SMEs in Indonesia. International Journal of Economics and Management, 11(S1), 35-44.

63. Salazar, A.L. (2012). The impact of financial decisions and strategy on small business competitiveness. Global journal of business research, 6 (2):93-94

64. Sanyal, R. (2019). Profit Theory 1. In S. Chand, Planned economy and growth.

65. Sarkar, C. R., \& Sarkar, A. (2013). Impact of working capital management practices on corporate performance: An empirical analysis of selected public sector oil and gas companies in India. International journal of management, 3(2), 17-28

66. Saunders, M., Lewis, P., \& Thornhill, A (2016). Research methods for Business Students ( $7^{\text {th }}$ ed.) Harlow: Pearson.

67. Siaw, F. (2014). Effect of demand side factors on access to external finance by micro, small and medium manufacturing enterprises in Kumasi metropolis, Ghana. Unpublished PhD Thesis, School of Business, Kenyata University, Kenya

68. Stoudt, B.G. (2014). Quantitative methods. In: Coghlan, D. \& Brydon-Millers, M (eds). The stage encyclopedia of Action Research. London: Sage pub.inc 1-8

69. Sweezy, P. M. (1943). The Review of Economic Statistics, 25(1), 93-96.

70. Syafri, (2012). Factors affecting bank profitability in Indonesia. Paper presented at the International Conference of Business and Management, Phuket, Thailand September, 2012. 
71. Tauringana, V., \&Afrifa. A. (2013). The relative importance of working capital management practices and its components to SMEs profitability. Journal of Small business and Enterprise Development, 20(3), 453-469 https://papers.ssm.com

72. Uwuigbe, U., Jafaru, J., \& Ajayi, A. (2012). Dividend policy and firm performance: A Study of listed firms in Nigeria. Accounting and Management Information System, 11(3), pp 442- 454 https://ideas.repec.org

73. Vijayakumar, A. (2011). Management of corporate liquidity and profitability: An empirical study. International Journal of marketing and Technology, 1(6), 168-169 https://www.indianjournals.com

74. Warrens, M.J (2014). On Cronbach's Alpha as the means of All possible k-Split Alphas. Advances in Statistics, 1-6 https://doi.org/10.1155/2014/742863

75. Wingaroja, G., \& O'Neil, S. (2018). A Study of Small Firm Exports, Policies and Support Institutions in Mauritius. Export and Industrial Development Division: Commonwealth Secretariat

76. Yensu. J., Yiadom. E. K.,\& Awatey. S. (2016). Financial Management Practices and Profitability of Business Enterprises in Obuasi Municipality, Ghana. Research Journal of Finance and Accounting Vol.7 (16) pp 66-76 www.iiste.org

77. Yohanes, D., Debela, K. L., \&Shibru. W. (2018). Effect of Financial Management Practices on profitability of Small-Scale Enterprise: Case study Hawassa city Administration, Ethiopia. IOSR Journal of Business and Management (IOSR-JBM) Vol. 20 (6) pp 39-45 www.iosrjournals.org

78. Yunis, M., Tarhini, A., \& Kassar, A. (2018). The role of ICT and Innovation in enhancing organizational performance: The catalyzing effect of corporate entrepreneurship. Journal of business Research, 88(June 2017), 344-356 www.sciencedirect.com

79. Zubair, A.,\& Muhammad, Y. G. (2013). Impact of working capital management practices on profitability. A Case of Pakistan Cement Industry. Interdisciplinary Journal of Contemporary research in Business, 5(2), 384-390. https://journal-archieves33.webs.com

\section{Figures}

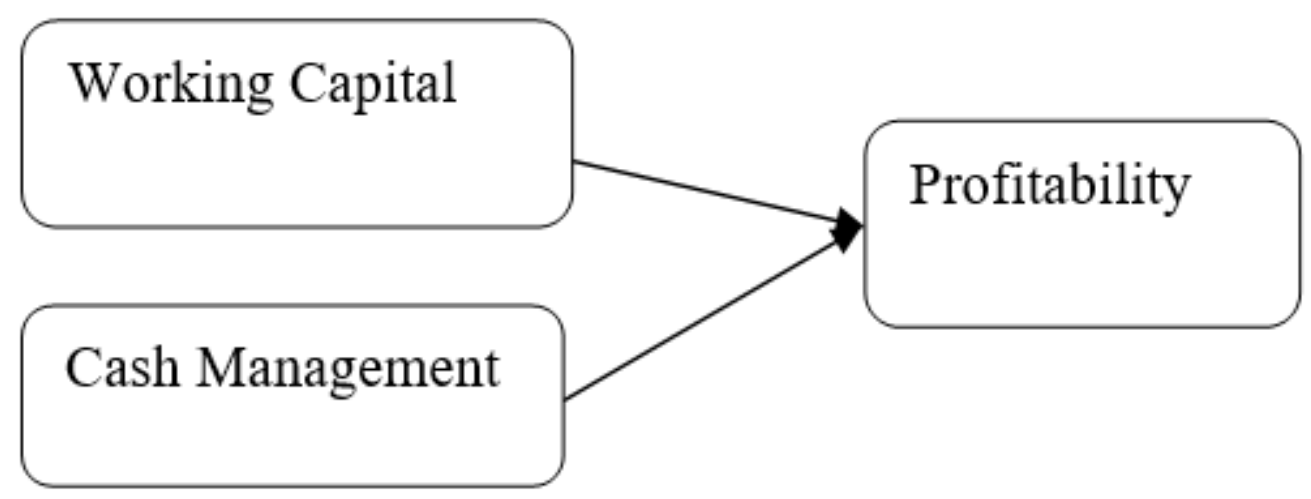

\section{Figure 1}


Conceptual Framework Source: Adopted from Nsagi and Kariuki (2017)

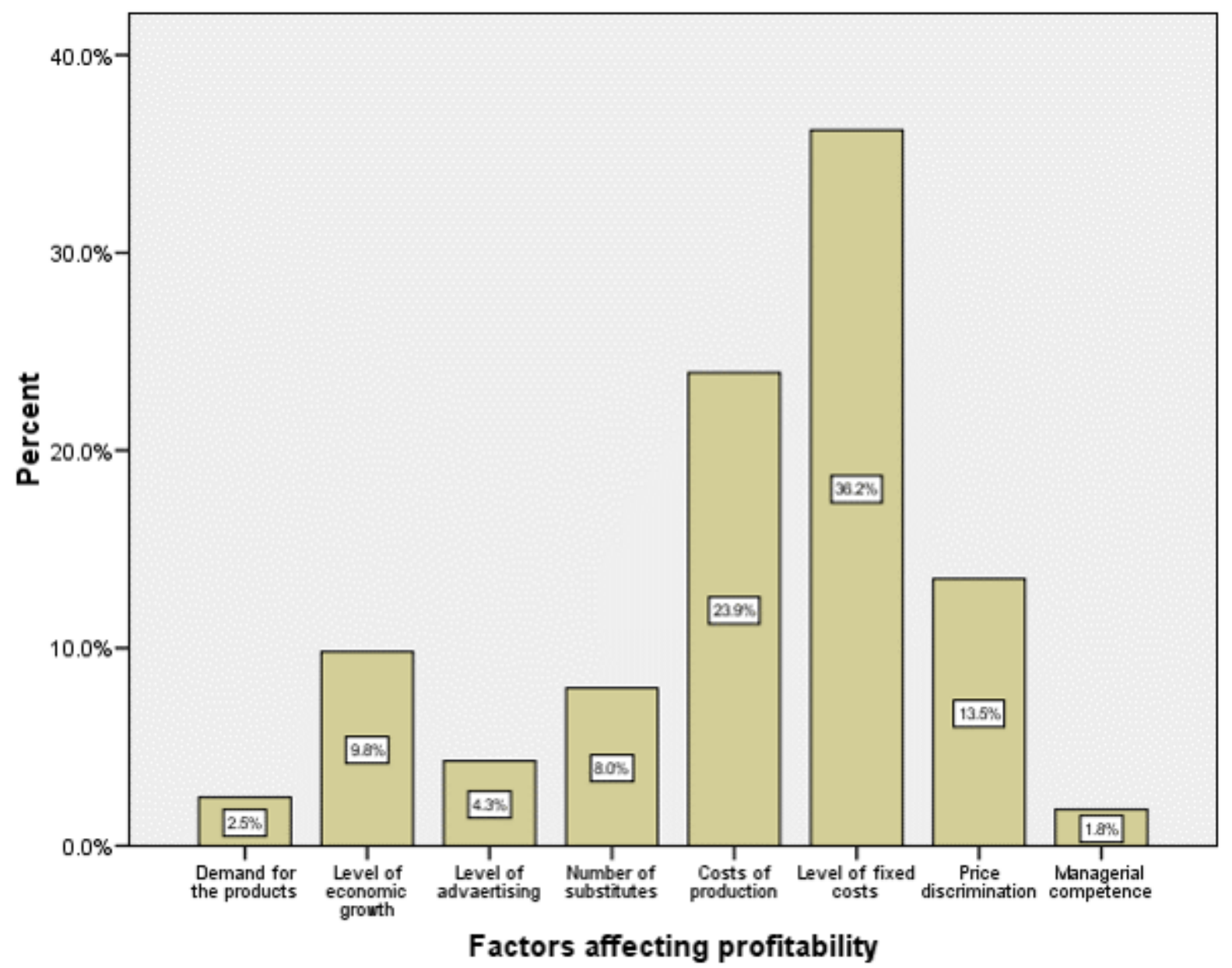

Figure 2

Factors affecting profitability 